\title{
The Capital Structure Choice and the Consumption Tax
}

\author{
Andreas Andrikopoulos ${ }^{1}$
}

\begin{abstract}
:
The consumption tax affects the consumer, but also affects the wealth of the producer because of the tax incidence effect. It affects cash flows from corporate investment, bears influence on capital budgeting choices on investment timing and financing and the respective agency conflicts between shareholders and creditors. In the context of irreversible investment, our model shows that consumption taxation delays investment and precipitates default. Furthermore, we find that the consumption tax has a negative effect on the agency costs of debt, the yield spreads and the optimal leverage ratio. Finally, the model also produces implications for governmental tax policy.
\end{abstract}

Key Words: Real Options, Consumption Tax, Tax Incidence, Agency Conflicts, Capital Structure

JEL Classification: D81, D92, E22, G31, H21, H22

\footnotetext{
* Note: Previous versions of this work have been presented at the 7th AFE Conference in Samos, the 19th MFS Conference in Barcelona and the 2010 B\&ESI Conference in Athens.

${ }^{1}$ Lecturer, Department of Business Administration, University of the Aegean, 8 Micahlon Str, 82100, Chios, Greece, Tel.: +302271035158, Fax:+302271035099, email: apa@aegean.gr
} 


\section{Introduction}

Capital structure decisions are instrumental in everyday managerial finance (Stretcher and Johnson 2011). The principal theoretical narratives on the capital structure choice have focused on the importance of the taxes that burden the supplier of capital on personal or a corporate level (Miller and Modigliani 1961; Modigliani and Miller 1963; Miller 1977). However, the supplier of capital is not the only entity whose income is taxed. For every dollar of corporate sales, there may be a consumption tax on the consumer. Since this is not a tax on the investor, but a tax on the consumer, the consumption tax is considered to be an irrelevant topic in the capital structure debate, but only seemingly so: the consumption tax affects the quantity and the price of the goods that are sold and it thus affects corporate cash flows, capital budgeting and investment financing. This is the "tax incidence" effect. Unless supply is perfectly elastic or demand is perfectly inelastic, the consumption tax ends up burdening not only the consumer but also the producer. Having been through the literature, there has not been any previous theoretical or empirical research to explore the effect of tax incidence and the consumption tax on leverage, yield spreads and agency conflicts between shareholders and creditors. In this direction, the following analysis demonstrates the negative effect of the tax incidence (on the producer) and the consumption tax on the investment and default thresholds, delaying entry and precipitating default. The tax incidence effect and the consumption tax are also shown to have a negative effect on yield spreads, agency cost of debt and the optimal leverage ratio.

The impact of consumption tax and tax incidence on investment timing and financing naturally affects corporate revenues and therefore government tax revenue from consumption and income taxes. In this model, government revenue is studied in a real options framework and optimal tax policies are estimated, calculating the level of the consumption tax that maximizes expected government revenue from taxation. The numerical results of this analysis provide us with a new approach to the "Ramsey rule" on consumption taxes, associating tax policies with optimal rules of irreversible investment under uncertainty.

We proceed with a brief literature review on the association between corporate debt and taxes. Section 3 sets up a theoretical model for our capital budgeting problem of irreversible investment. Section 4 presents numerical results on the effects of the consumption tax on investment timing, agency costs of debt, yield spreads and optimal leverage. Section 5 calculates expected government revenues from taxes and suggests revenue maximizing tax policies, based on the effect of the consumption tax on investment timing and financing. The final section concludes the paper. 


\section{An Outline of the Debt-and-Narrative}

Trading tax shields of corporate debt for bankruptcy costs: this is the main platform of the real options approach to the interaction between operating and financing decisions. Of course, this modeling idea is not fundamentally a realoptions one. Laying the foundations of modern microeconomic thought on corporate finance, Miller and Modigliani (1961) and Modigliani and Miller (1963) showed that a firm could actually increase its value without affecting its operating income, implementing an appropriate choice of the capital structure mix. The optimal magnitude of debt financing depends on the effects of the tax shields of corporate debt and the costs of financial distress. In this framework, it is the tax rate on corporate income that drives the capital structure choice. This theoretical result has generated significant implications for the theory and practice of corporate finance and there has been empirical evidence to show a positive effect of corporate income tax on the extent of debt financing (e.g. Graham 1999; Wu and Ye 2009). Much of the theoretical implications were structured on the suggestion that the original modeling assumptions of Modigliani and Miller were not realistic. One of the major streams of thought that aimed at refining the capital structure landscape and making it more realistic was the real options paradigm. Incorporating irreversibility and uncertainty in the capital budgeting problem, the real options models provided a new insight to the problem of capital structure and the conflicting incentives of creditors and shareholders. On the trade-off theory of capital structure, these real options models have produced theoretical results on the effect of corporate income tax on the capital structure choice. In the real options framework, the tax rate has been found to have an increasing effect on the optimal leverage ratio and respective yield spreads (Leland 1994; Childs et al. 2005; Mauer and Sarkar 2005) as well as on the agency costs of corporate debt (Childs et al. 2005; Mauer and Sarkar 2005). The standard trade-off setting of capital structure choice has been further refined to incorporate tax convexity (Sarkar 2008) and the effect of personal taxes (Gamba et al, 2008; Morellec and Schürhoff 2009).

All these papers have focused on the dependence of the capital structure choice on corporate taxes and income taxes. Taxes, however, are not solely imposed on corporate profits and owners of corporate securities. They are also imposed on consumers; hence they affect corporate cash flows, capital budgeting and, thereof, the assessment of competing investment alternatives. This paper aims at covering this gap in the capital structure literature and also at discussing the optimal consumption tax as a function of corporate investment and financing decisions. 


\section{Investment Timing, Capital Structure Choice and Government Tax Revenue}

Let's consider a firm whose value consists of the right to invest in a project to manufacture and sell a single product. We assume that this investment right is exclusive and also perpetual. The operating and financing decisions are made by a manager who is assumed to be completely aligned with the interests of shareholders. Operating problems are associated with the decision to start and abandon the operations and financing problems amount to security design for investment financing. The project's cost is $\$ I$ and it can be financed with a new equity issue. If the shareholders do not contribute all the needed capital to finance the investment, the firm can resort to a debt issue, equal to $\$ X$, with coupon $\$ R$. Should the firm default on its debt, the creditors take over the management and ownership. However, due to bankruptcy and reorganization costs as well as less efficient managerial skills, the project's operating income will be reduced at a rate equal to $b, 0<b<1$. Upon project implementation, the firm produces and sells one product per unit of time, at a price $\$ Y$ and an operating cost $\$ C$. We assume that the market outcome on the product's price follows a Geometric Brownian Motion:

$$
d Y=\mu Y d t+\sigma Y d z
$$

where $\mu$ is the risk-neutral drift rate, $\sigma$ the volatility of annual returns and $d z$ is the increment of a standard Wiener process. The government sets the tax rates before the initiation of the project: the firm's income is taxed at a linear tax schedule $\tau$ and there is also a consumption tax of $\$ T$ per unit of product bought. Legally, the consumption tax falls exclusively on the consumers, the firm just collecting the tax, on behalf of the government. Economically however, things can be different. A consumption tax tends to increase the market price and this means that demand decreases and the firm ends up earning (per unit of product) less than what it would earn in a framework without consumption taxes. In this setting, part of the burden of consumption tax may fall on the producer. This is a tax incidence effect and the magnitude of the tax incidence on the producers depends on the elasticities of demand and supply of the product. Let $k$ be a tax incidence coefficient: the firm therefore earns $Y-k T, 0 \leq k \leq 1$. When demand is perfectly inelastic or supply is perfectly elastic, the (consumption) tax burden falls on the consumer and we have $k=0$. On the other hand, when demand is perfectly elastic or supply is perfectly inelastic, the tax burden falls on the producer and $k=12$.

\footnotetext{
${ }^{2}$ Assuming that we model a small firm in a large industry, the magnitude of tax incidence and the price process are exogenous to the firm (e.g. a small oil company does not affect oil prices). The extent of tax
} 


\subsection{Unlevered asset value}

We assume a frictionless, complete market for capital assets, with no information asymmetries and no opportunities for arbitrage. In such an investment setting, standard replication arguments can show that the value of the firm, after the project has been implemented, satisfies the following partial differential equation:

$$
\frac{1}{2} \sigma^{2} \mathrm{Y}^{2} \mathrm{~V}_{\mathrm{YY}}^{\mathrm{U}}+\mu \mathrm{YV}_{\mathrm{Y}}^{\mathrm{U}}-r V^{U}+Y-k T-C=0
$$

where $r$ is the risk free rate of return.

The general solution of $(2.1)$ is

$$
V^{U}(Y)=\left(\frac{Y}{r-\mu}-\frac{\mathrm{C}+\mathrm{kT}}{\mathrm{r}}\right)(1-\tau)+\mathrm{A}_{1} Y^{\gamma}+\mathrm{A}_{2} Y^{\delta}, \quad \mathrm{Y}>\mathrm{Y}_{\mathrm{A}},
$$

where $Y_{A}$ is the abandonment threshold,

$$
\begin{aligned}
& \gamma=\frac{1}{2}-\frac{\mu}{\sigma^{2}}+\sqrt{\frac{2 r}{\sigma^{2}}+\left(\frac{\mu}{\sigma^{2}}-\frac{1}{2}\right)^{2}}>1 \\
& \delta=\frac{1}{2}-\frac{\mu}{\sigma^{2}}-\sqrt{\frac{2 r}{\sigma^{2}}+\left(\frac{\mu}{\sigma^{2}}-\frac{1}{2}\right)^{2}}<0
\end{aligned}
$$

and $A_{1}$ and $A_{2}$ are constants to be determined subject to the boundary conditions

$$
\begin{gathered}
V^{U}\left(Y_{A}\right)=0 \quad(3 \mathrm{a}) \\
\left.\frac{\partial V^{U}}{\partial Y}\right|_{Y=Y_{A}}=0 \\
\lim _{Y \rightarrow \infty} V^{U}=\left(\frac{Y}{r-\mu}-\frac{c+k \tau}{r}\right)(1-\tau) \\
(3 \mathrm{c}) .
\end{gathered}
$$

Applying (2.2) to (2.3a), (2.3b) and (2.3c) yields

incidence (k) is the outcome of (the elasticities of) supply and demand on an industry level. We adopt the industry-wide $\mathrm{k}$ for the small company, by assuming that the small firm is the "average" firm in the industry, a representative one. 


$$
V^{U}(Y)=\left(\frac{Y}{r-\mu}-\frac{C+k T}{r}\right)(1-\tau)-\left(\frac{Y_{A}}{r-\mu}-\frac{C+k T}{r}\right)(1-\tau)\left(\frac{Y}{Y_{A}}\right)^{\delta}
$$

and

$$
Y_{A}=-\frac{\delta(r-\mu)(c+k T)}{r(1-\delta)}
$$

\subsection{Levered firm value}

In the case of the levered firm, the investment has been financed partly with debt: the shareholders' financing and operating options include the option to default and the project's cash flows now include an outflow equal to debt coupon $R$. Applying the same valuation arguments as in the case of the unlevered firm, the value of equity $E$ in the case of the levered firm is

$$
\begin{aligned}
& E(Y)=\left(\frac{Y}{r-\mu}-\frac{C+R+k T}{r}\right)(1-\tau)-\left(\frac{Y_{D}}{r-\mu}-\frac{C+R+k T}{r}\right)(1-\tau)\left(\frac{\mathrm{Y}}{\mathrm{Y}_{\mathrm{D}}}\right)^{\delta} \\
& , Y>Y_{D} \\
& \text { where } Y_{D}=-\frac{\delta(r-\mu)(C+R+k T)}{(1-\delta) r} \text { is the default trigger. }
\end{aligned}
$$

The value of corporate debt $D$, after the investment option has been exercised, satisfies the following partial differential equation

$$
\frac{1}{2} \sigma^{2} Y^{2} D_{Y Y}+\mu Y D_{Y}-r D+R=0(2.4)
$$

The general solution to $(4)$ is of the form

$$
D(Y)=A_{3} Y^{\gamma}+A_{4} Y^{\delta}+\frac{R}{r}(2.5)
$$

$A_{3}$ and $A_{4}$ are calculated subject to boundary conditions

$$
\begin{aligned}
& \lim _{Y \rightarrow \infty} D(Y)=\frac{k}{p}(2.6 a) \text { and } \\
& D\left(Y_{D}\right)=(1-b) V^{U}\left(Y_{D}\right)(2.6 b) .
\end{aligned}
$$

Boundary condition (2.6b) demonstrates our modeling assumption that the creditors receive the unlevered value of the firm, when default occurs. Substituting $(2.6 a)$ and $(2.6 b)$ in $(2.5)$, we find the value of corporate debt

$$
D(Y)=\frac{\bar{F}}{r}+\left[(1-b) V^{U}\left(Y_{D}\right)-\frac{\pi}{r}\right]\left(\frac{Y}{Y_{D}}\right)^{\delta}
$$


Having calculated the value of debt, the value of the levered firm $V^{L}$ can be estimated as the sum of the value of equity and the value of debt

$$
V^{L}(Y)=V^{U}(Y)-b V^{U}\left(Y_{D}\right)\left(\frac{Y}{Y_{D}}\right)^{\delta}+\frac{\tau R}{r}\left[1-\left(\frac{Y}{Y_{D}}\right)^{\delta}\right]
$$

The value of the levered firm equals the value of the unlevered firm minus the present value of expected bankruptcy costs plus the present value of expected tax shields of corporate debt.

\subsection{Pricing the option to invest}

The valuation of the option to invest can be structured on equity-value maximization or on firm-value maximization. We define the former case as "secondbest" whereas we define the latter as "first-best". The value of the option to invest $F(\boldsymbol{Y})$ satisfies the following partial differential equation

$$
\frac{1}{2} \sigma^{2} Y^{2} F_{Y Y}+\mu Y F_{Y}-r F=0(2.7)
$$

The general solution to $(2.7)$ is of the form

$$
F(Y)=A_{5} Y^{\gamma}+A_{6} Y^{\delta}(2.8), Y<Y_{I}^{2}
$$

where $Y_{I}^{2}$ is the investment threshold that maximizes the value of equity, under the second-best scenario. $A_{\mathrm{5}}, A_{\mathrm{6}}$ are constants to be determined subject to the boundary conditions

$$
\begin{gathered}
F\left(Y_{l}^{2}\right)=E\left(Y_{l}^{2}\right)-(I-X)(2.9 a) \\
\left.\frac{\partial F}{\partial Y}\right|_{Y=Y_{I}^{2}}=\left.\frac{\partial E}{\partial Y}\right|_{Y=Y_{I}^{2}}(2.9 b)
\end{gathered}
$$

We can find the second-best value of the option to invest by applying $(2.9 a)$ and $(2.9 b)$ to $(2.8)$.

$$
F(Y)=\left[E\left(Y_{I}^{2}\right)-(I-X)\right]\left(\frac{Y}{y_{I}^{2}}\right)^{Y}
$$

The second-best investment threshold satisfies the following implicit equation 


$$
\left(\frac{\delta-\gamma}{y}\right)\left(\frac{Y_{D}}{r-\mu}-\frac{c+k T+R}{r}\right)\left(\frac{Y_{l}^{2}}{Y_{D}}\right)^{\delta}+\left(\frac{\gamma-1}{y}\right) \frac{Y_{l}^{2}}{r-\mu}-\frac{c+k T+R}{r}-\frac{E-X}{1-\tau}=0
$$

The value $X$ of the debt that will be used to finance the investment can be derived from the second-best investment threshold: the lenders will grant credit knowing that the operating policy will be the second-best one and debt financing will therefore be $D\left(Y_{I}^{2}\right)$. In this context, an optimal leverage ratio will be the ratio of debt to project value, for the coupon level $R$ which maximizes the value of the real option to invest. Respectively, yield spreads are defined as the difference between the interest burden on corporate debt and the risk free rate of interest $\frac{R}{D\left(r_{f}^{2}\right)}-r$.

In a similar vein, applying value-matching and smooth-pasting conditions to the maximization of the firm value, we can obtain the value of the option to invest $F^{1}$ under a first-best operating and investment policy:

$$
F^{1}(Y)=\left[V^{E}\left(Y_{I}^{\mathbf{1}}\right)-I\right]\left(\frac{Y}{Y_{T}^{2}}\right)^{\gamma}
$$

where $Y_{I}^{\mathbf{l}}$ is the value maximizing (first-best) investment trigger and can be found through the smooth pasting condition and the respective implicit equation

$$
\begin{gathered}
\left(\frac{d-\gamma}{\gamma}\right) \frac{(1-b) Y_{A}}{(\gamma-\mu)}\left(\frac{Y_{l}^{1}}{Y_{A}}\right)^{\delta}+\left(\frac{d-\gamma}{\gamma}\right)\left[h\left(\frac{Y_{D}}{r-\mu}-\frac{c+k P}{r}\right)+\frac{\tau R}{(1-\tau) \gamma}\right]\left(\frac{Y_{l}^{2}}{Y_{D}}\right)^{\delta} \\
+\left(\frac{\gamma-1}{\gamma}\right) \frac{Y_{I}^{2}}{\gamma-\mu}-\frac{C+k T}{\gamma}+\frac{\tau R}{(1-\tau) r}-\frac{I}{1-\tau}-0
\end{gathered}
$$

The fact that operating -and therefore financing- policies are different in equity maximization and value maximization yields agency costs of debt (e.g. Mauer and Triantis, 1994; Mauer and Ott, 2000). These costs, $A C_{z}$ can be measured with the loss in firm value under second-best policies:

$$
A C=\frac{F^{1}-F}{F^{1}} .
$$

\section{Effects of consumption taxation on operating and financing decisions}

To the extent that consumption taxes reduce corporate profitability through the effect of tax incidence on the producer, indirect taxation has an impact on investment timing and hence on aggregate output, the choice of leverage and the outcome of agency conflicts between shareholders and creditors. The main results of our analysis are: 
Result 1: The optimal investment and default thresholds are increasing in the consumption tax and the tax incidence on the producer.

Result 2: The value of the option to invest, the optimal leverage ratio, the agency costs of debt and the yield spreads on corporate debt are decreasing in the consumption tax and the tax incidence on the producer.

For the deduction of these numerical results we employ the following basecase parameters:

$\begin{aligned} \text { Output price: } & Y=\$ 1 \\ \text { Coupon payment } & \mathbb{R}=\$ 1 \\ \text { Operating cost } & C=\$ 0.25 \\ \text { Investment cost } & I=\$ 10 \\ \text { Risk free rate of interest } & r=0.04 \\ \text { Risk-neutral drift rate } & \mu=0.01 \\ \text { Bankruptcy costs } & D=0.3 \\ \text { Corporate tax rate } & \tau=0.4 \\ \text { Volatility of annual returns } & \sigma=0.3\end{aligned}$

Figure 1. Sensitivity of option value to consumption tax, for varying tax incidence

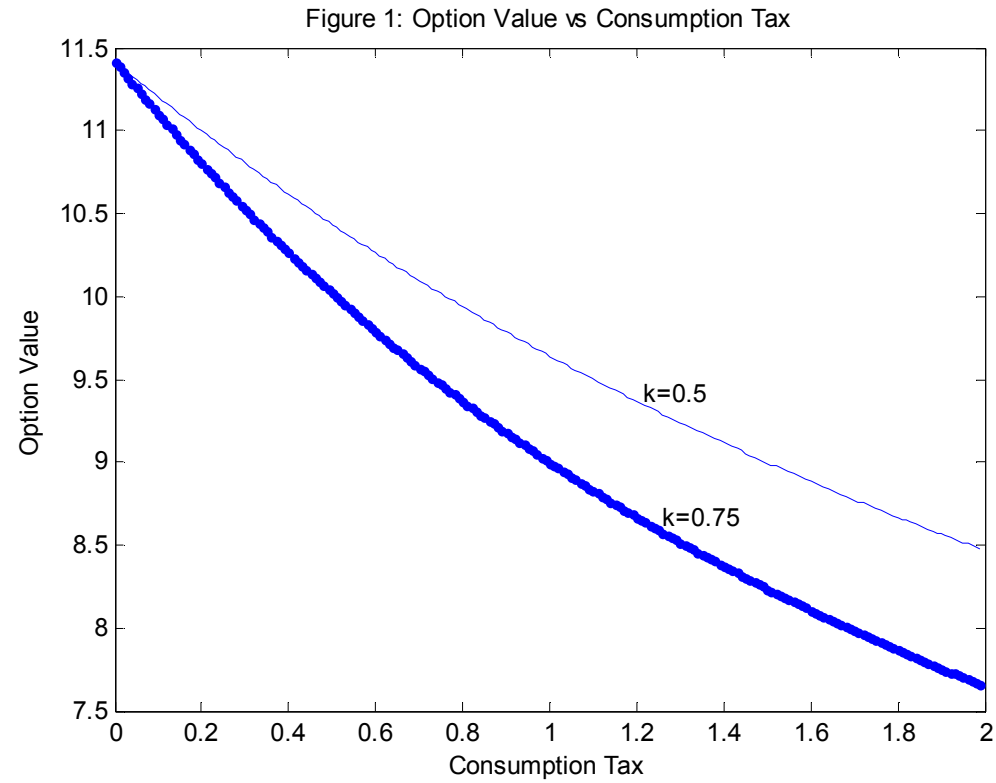

Notes: Output price $(Y)_{\text {is } \$ 1 \text {, coupon payment }}(R)_{\text {is } \$ 1 \text {, operating cost }}(C)_{\text {is } \$ 0.25 \text {, }}$ investment cost (I) is $\$ 10$, risk free rate of interest $(r)$ is 0.04 , drift rate $(\mu)$ is 0.01 , bankruptcy costs are 0.3 , tax rate for corporate income is 0.4 and volatility of annual returns is 0.3 . 
Figure 2a. Sensitivity of first-best (FB) and second-best (SB) investment trigger to consumption tax

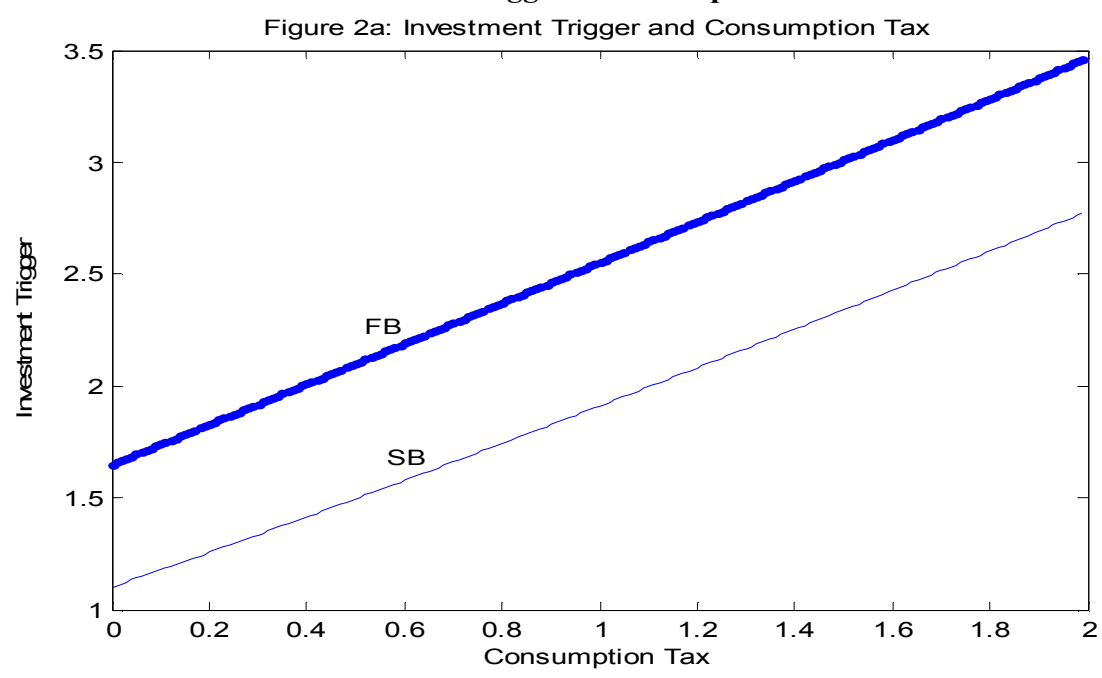

Note: Output price $(Y)_{\text {is } \$ 1 \text {, coupon payment }}(R)$ is $\$ 1$, operating cost $(C)$ is $\$ 0.25$, investment cost (I) is $\$ 10$, risk free rate of interest $(r)$ is 0.04 , drift rate $(\mu)$ is 0.01 , bankruptcy costs are 0.3 , tax rate for corporate income is 0.4 , volatility of annual returns is 0.3 and the tax incidence coefficient $(k)$ is 0.5 .

Figure 2b. Sensitivity of first-best (FB) and second-best (SB) investment trigger to tax incidence

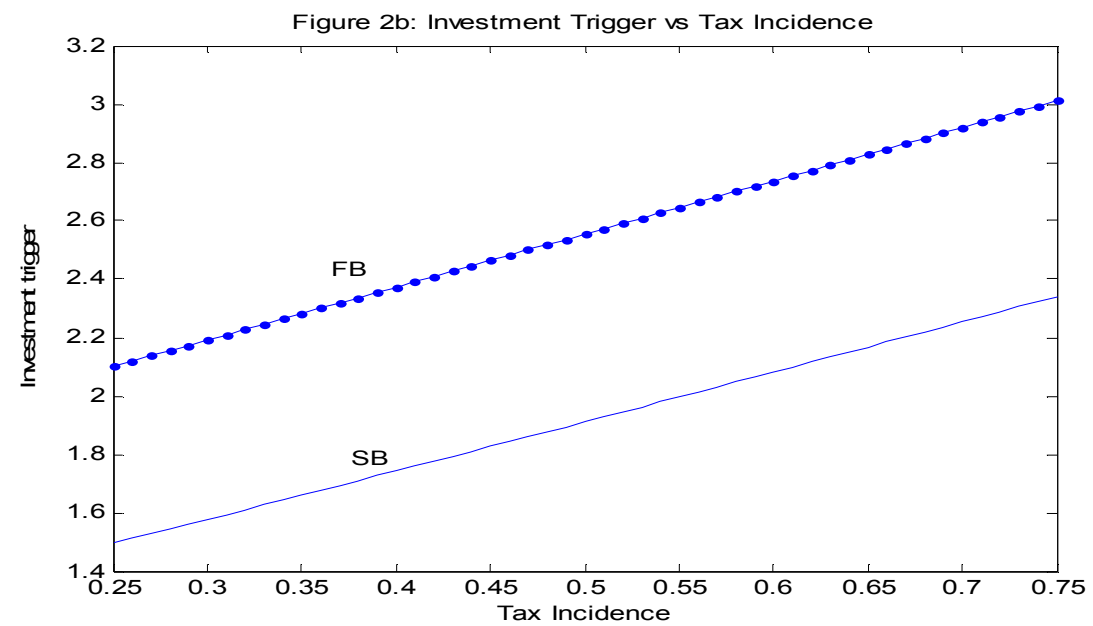

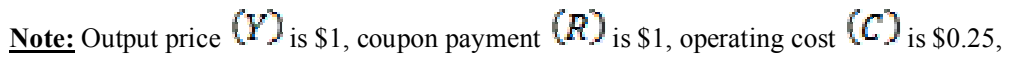
investment cost (I) is $\$ 10$, risk free rate of interest $(r)$ is 0.04 , drift rate $(u)$ is 0.01 , bankruptcy costs are 0.3 , tax rate for corporate income is 0.4 , the volatility of annual returns is 0.3 and the consumption tax $(T)_{\text {is }} \$ 0.5$. 
Figure 3. Sensitivity of default trigger to consumption tax, for varying tax incidence

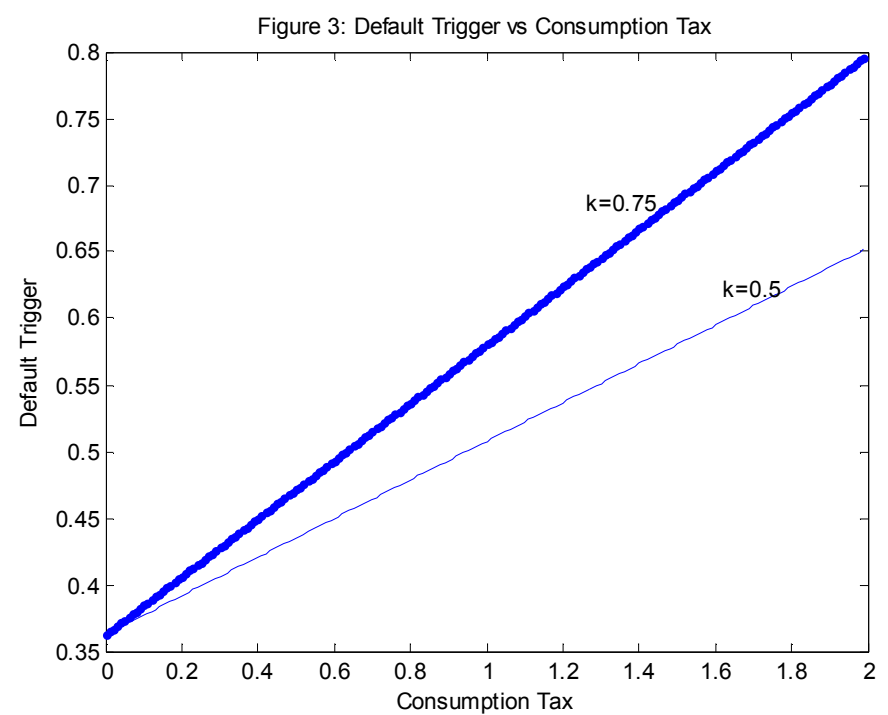

Note: Output price $(Y)$ is $\$ 1$, coupon payment $(R)$ is $\$ 1$, operating cost $(C)$ is $\$ 0.25$, investment cost (I) is $\$ 10$, risk free rate of interest $(r)$ is 0.04 , drift rate $(u)$ is 0.01 , bankruptcy costs are 0.3 , tax rate for corporate income is 0.4 and volatility of annual returns is 0.3 .

Result 1 comes from the negative effect of the consumption tax and the tax incidence effect on profitability. The profitability is affected not only per unit of product sold through tax incidence, but also through the fact that investment timing determines the quantity of units sold between entry and exit. The investment opportunity is less attractive for higher consumption tax rates when the tax incidence on the producer is positive $(k>0)$. Higher consumption tax rates, matched with higher levels of tax incidence reduce the part of cash inflows which actually constitutes revenue for the firm (the rest being a tax burden on the consumer). This means that the investment opportunity -in a second-best investment settingdecreases in value (Fig. 1) and therefore the project is delayed; we observe the higher investment threshold in Fig. 2a and Fig. 2b. Decreased profitability also leads to earlier exit from the project and default (Fig. 3). We see in Fig. 2a and $2 b$ that, for all levels of consumption tax and tax incidence, the second-best policy induces overinvestment. 
Figure 4. Sensitivity of agency costs of debt to consumption tax, for varying tax incidence

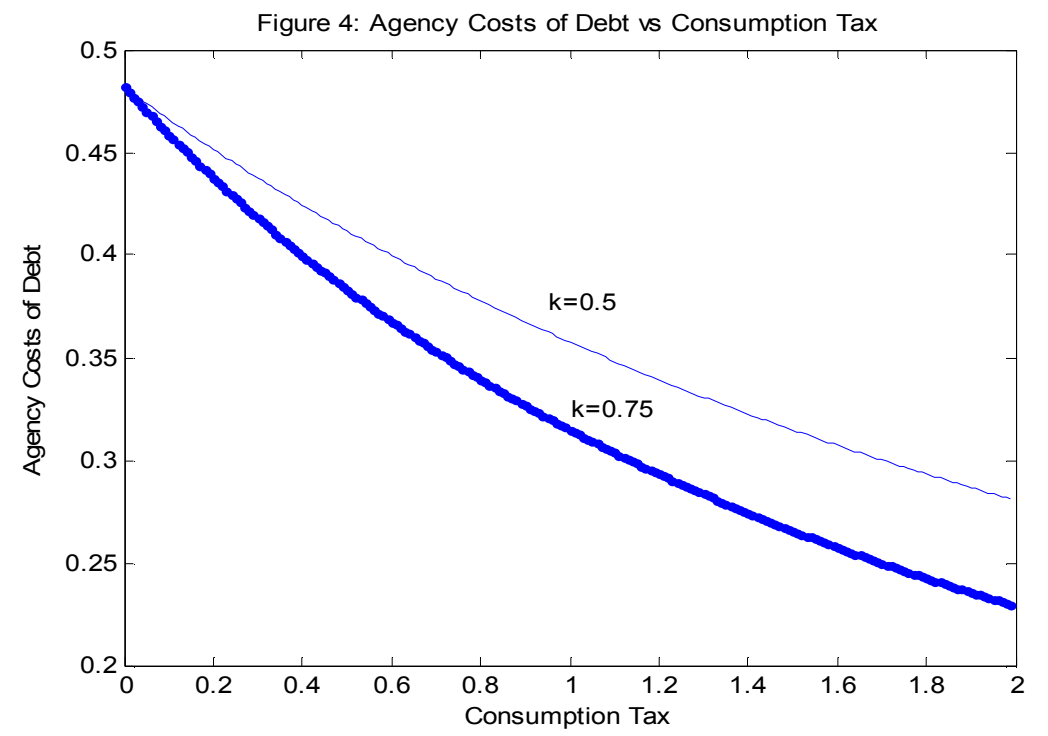

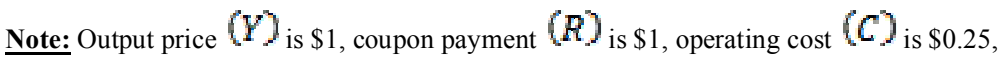
investment cost (I) is $\$ 10$, risk free rate of interest $(r)$ is 0.04 , drift rate $(\mu)$ is 0.01 , bankruptcy costs are 0.3 , tax rate for corporate income is 0.4 and volatility of annual returns is 0.3 .

Figure 5. Sensitivity of yield spreads to consumption tax, for varying tax incidence

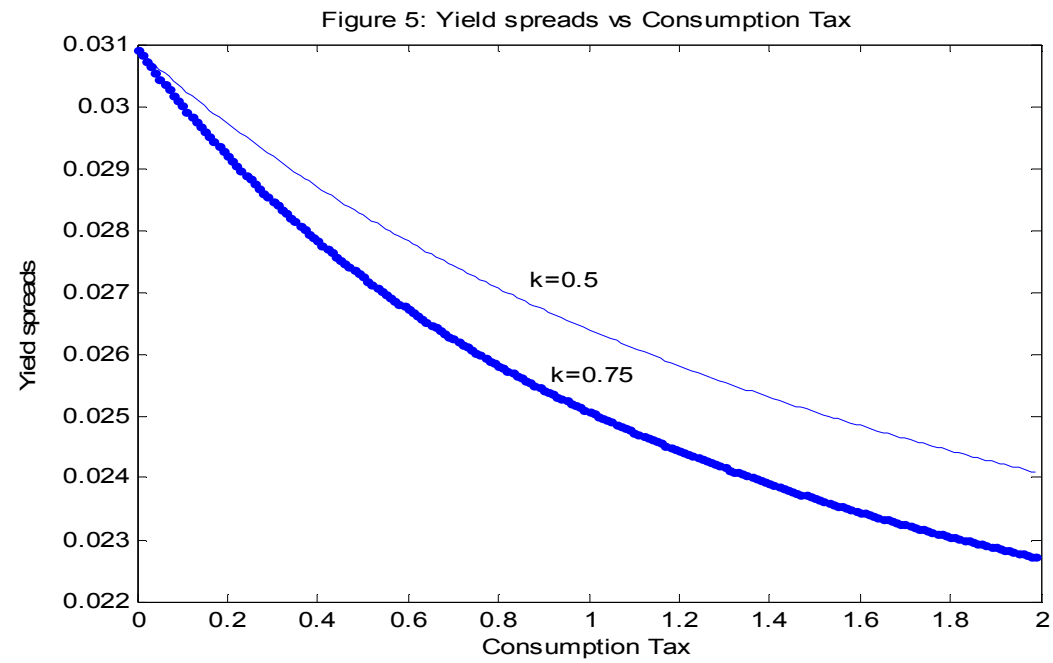

Note: Output price $(Y)_{\text {is } \$ 1 \text {, coupon payment }}(R)_{\text {is } \$ 1 \text {, operating cost }}(C)_{\text {is } \$ 0.25 \text {, }}$ investment cost (I) is $\$ 10$, risk free rate of interest $(r)$ is 0.04 , drift rate $(\mu)$ is 0.01 , bankruptcy costs are 0.3 , tax rate for corporate income is 0.4 and volatility of annual returns is 0.3 . 
Figure 6. Sensitivity of deviations from first-best investment timing to consumption tax, for varying tax incidence

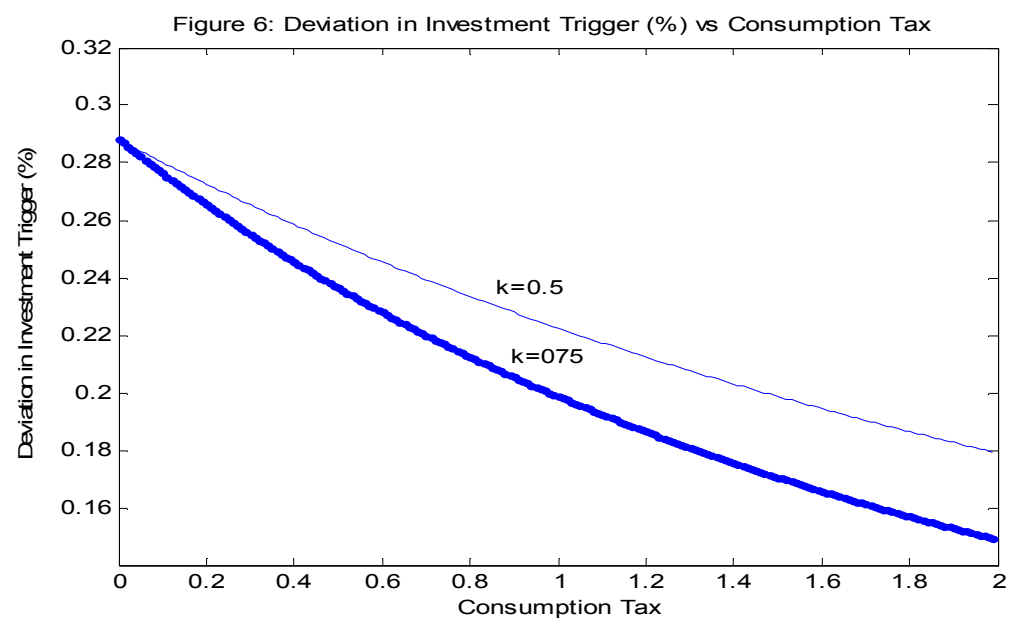

Note: Deviations are measured with the percentage difference between the first-best $Y_{I}^{1}$ and the second-best investment trigger $Y_{l}^{2}, \frac{Y_{I}^{1}-Y_{I}^{2}}{Y_{T}^{2}}$. Output price $(Y)$ is $\$ 1$, coupon payment $(R)_{\text {is }}$ $\$ 1$, operating cost $(C)$ is $\$ 0.25$, risk free rate of interest $(r)$ is 0.04 , investment cost (I) is $\$ 10$, drift rate $(\mu)$ is 0.01 , bankruptcy costs are 0.3 , tax rate for corporate income is 0.4 and the volatility of annual returns is 0.3 .

The overinvestment result accounts for the difference between the first-best and the second-best project value, the agency costs of debt. The fact that investment is, in part, financed with debt means that the shareholders have a strong inventive to speed up investment so as to realize the tax benefits of debt, thus increasing the risk that is associated with suboptimal investment and decreasing the welfare of the creditors. As the creditors are aware of these deviations from first-best investment strategies, they ask for higher yield spreads in order to extend credit to equitymaximizing shareholders. The effect of consumption tax and the tax incidence effect on agency costs of debt and yield spreads depends on the effect of consumption tax on deviations from first-best operating policy. Fig. 4 shows that the agency costs of debt are decreasing in the consumption tax and the tax incidence on the firm. The decrease in the agency costs of debt -due to an increase in the consumption tax- and the respective decrease in the yield spreads (Fig. 5) can be explained with the effect that the consumption tax has on deviations from first-best investment. Fig. 6 shows that the percentage deviation from first-best investment timing is decreasing in the consumption tax and the tax incidence on the firm. It is because of these suboptimal investment effects, that agency costs of debt and yield spreads are decreasing in the consumption tax.

As we saw in Fig. 3, the effect of consumption tax and tax incidence on operating policy involves not only investment timing but also the decision to default. 
The dependence of the default trigger on the consumption tax drives the effects of the consumption tax and tax incidence on optimal leverage.

Figure 7. Sensitivity of second-best optimal leverage to consumption tax, for varying tax incidence

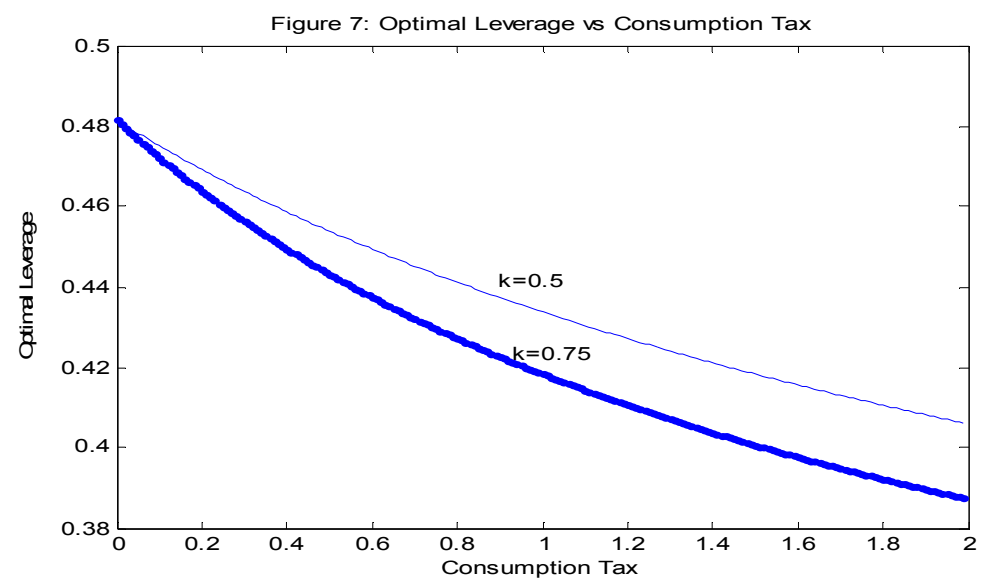

Note: Output price $(Y)$ is $\$ 1$, coupon payment $(R)$ is $\$ 1$, operating cost $(C)$ is $\$ 0.25$, investment cost (I) is $\$ 10$, risk free rate of interest $(r)$ is 0.04 , drift rate $(\mu)$ is 0.01 , bankruptcy costs are 0.3 , tax rate for corporate income is 0.4 and volatility of annual returns is 0.3 .

\section{Figure 8. Sensitivity of tax shields and bankruptcy costs to consumption tax, for varying tax incidence}

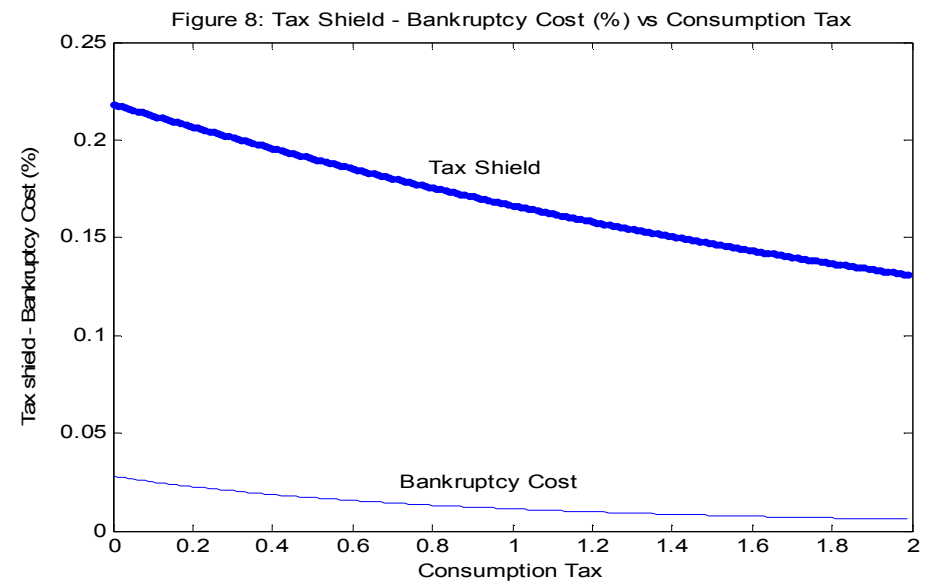

Note: Tax shields and bankruptcy costs are measured as a percentage of firm value. Output price $(Y)$ is $\$ 1$, coupon payment $(R)$ is $\$ 1$, operating cost $(C)$ is $\$ 0.25$, investment cost (I) is $\$ 10$, risk free rate of interest $(r)$ is 0.04 , drift rate $(\mu)$ is 0.01 , bankruptcy costs are 0.3 , tax rate for corporate income is 0.4 and volatility of annual returns is 0.3 . 
As default happens early due to the tax burden from the consumption tax and the tax incidence on the firm, the value of tax shields of corporate debt decreases and the optimal level of debt financing also decreases (Fig. 7). Actually, the leverage ratio depends on both the tax shields and the bankruptcy costs of debt, but it is the tax shields that significantly affect the capital structure choice: the tax shields account for a larger portion of project value, as can be seen in Fig. 8.

\section{Taxing the Corporate Income: The Government's Perspective}

While the real options approach has been applied to explore the effect of taxes on operating and financing decisions, there has been no attention -in this context- to a principal institutional motivation for taxes, which is the increase in government revenue. Since government revenue is contingent on the market price of project output and the firm's investment decisions, our real option setting can show the dynamics of government revenue from taxes. Especially with respect to the consumption tax, its effect on government revenue has been a subject of major controversy (e.g. Atkinson and Stiglitz 1976; Gordon et al. 2004); an increase in the tax rate may have the arithmetic effect of an increase in tax revenue but it may also have the economic effect of decreasing output and the tax base. The effect of consumption tax on investment -in our real option model- is based on the effect of the consumption tax on investment timing.

In the case of a project that has been financed with debt, the government's revenue from taxes consists of the income tax on corporate earnings and the consumption tax. Hence, the government revenue per unit of time is $\tau(Y-C-R-k T)+T$ and the value of the government's stake $G_{\text {On }}$ the firm's proceeds satisfies the following partial differential equation

$$
\frac{1}{2} \sigma^{2} Y^{2} G_{Y Y}+\mu Y G_{Y}-r G+\tau(Y-C-R-k T)+T=0, \quad Y<Y_{D}(4.1)
$$

The general solution of $(4.2)$ is

$$
G(Y)=A_{7} Y^{\gamma}+A_{\mathrm{g}} Y^{\delta}+\frac{\tau Y}{r-\mu}-\frac{\tau(C+R)-(1-k \tau) T}{r}(4.3) .
$$

$A_{7}$ and $A_{\mathrm{g}}$ are constants to be determined with the boundary conditions

$\lim _{Y \rightarrow \infty} G(Y)=\frac{\tau Y}{r-\mu}-\frac{\tau C+\tau R-(1-k \tau T}{r}(4,4 \alpha)$ and

$G\left(Y_{D}\right)=G^{D}\left(Y_{D}\right)(4,4 b)$.

$G^{D}$ is the value of the government's stake on the firm's proceeds in case of default. Then the creditors take over and the (unlevered) firm's operating income falls by a fraction of $b . G^{D}$ is therefore 


$$
G^{D}(Y)=A_{9} Y^{\gamma}+A_{10} Y^{\delta}+\frac{\tau(1-b) Y}{r-\mu}-\frac{\tau(1-b) c-(1-(1-b) k r) T}{r}(4.5)
$$

We can calculate $A_{9}$ and $A_{10 w i t h}$ the boundary conditions

$$
\begin{gathered}
\lim _{Y \rightarrow \infty} G^{D}(Y)=\frac{\tau(1-b) Y}{r-\mu}-\frac{\tau(1-b) c-(1-\tau(1-b) k) T}{r}(4.6 a) \\
G^{D}\left(Y_{A}\right)=0(4.6 b) .
\end{gathered} \text { and }
$$

Using (4.6a) and (4.6b), we find that

$$
\begin{aligned}
G^{D}(Y)=\frac{\tau(1-b) Y}{r-\mu}-\frac{\tau(1-b) C-(1-(1-b) k \tau) T}{r} & \\
& -\left(\frac{\tau(1-b) Y_{A}}{r-\mu}-\frac{\tau(1-b) C-(1-(1-b) k \tau) T}{r}\right)\left(\frac{Y}{Y_{A}}\right)^{\delta}(4.7) .
\end{aligned}
$$

Using (4.7), we can apply $(4.4 \alpha)$ and $(4.4 b)$ to $(4.3)$ : the value of the government's stake on the firm's proceeds is

$$
G(Y)=\left[\frac{\tau Y}{r-\mu}+\frac{(1-\tau k) T-\tau(C+R)}{r}\right]+\left[G^{D}\left(Y_{D}\right)-\frac{\tau Y_{D}}{r-\mu}-\frac{(1-\tau k) T-\tau(C+R)}{r}\right]\left(\frac{Y}{Y_{D}}\right)^{\delta}
$$

Since government revenue starts flowing only after the project has started, we need to incorporate the effect of investment timing on government revenue. The present value of expected government revenue $G^{P}$, conditional upon the project starting, satisfies the following partial differential equation

$$
\frac{1}{2} \sigma^{2} Y^{2} G_{Y Y}^{P}+\mu Y G_{Y}^{P}-r G=0(4.8)
$$

(4.8) is solved subject to boundary conditions, assuming a second-best operating setting:

$$
\begin{gathered}
G^{D}\left(Y_{I}^{2}\right)=G\left(Y_{I}^{2}\right)(4.9 a) \\
G^{D}(0)=0(4.9 b) .
\end{gathered}
$$

The solution of $(4.8)$ is of the form

$$
G^{P}(Y)=A_{11} Y^{\gamma}+A_{12} Y^{\delta}(4,10)
$$


Substituting $(4.9 a)$ and $(4.9 b)$ to $(4.10)$, we get the value of the government's perspective revenues from taxation

$$
G^{F}(Y)=G\left(Y_{I}^{2}\right)\left(\frac{Y}{Y_{Y}^{2}}\right)^{Y}
$$

Figure 9. Sensitivity of expected government tax revenue to consumption tax

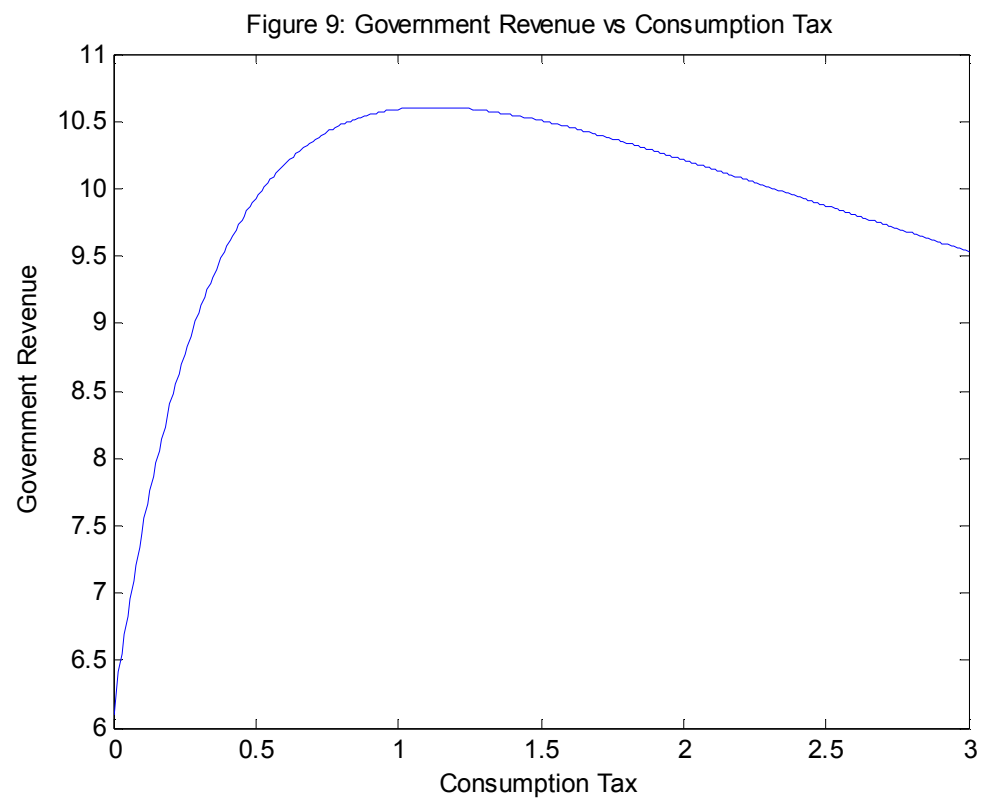

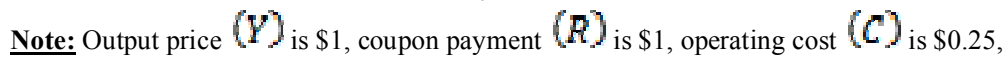
investment cost (I) is $\$ 10$, risk free rate of interest $(r)$ is 0.04 , drift rate $(u)$ is 0.01 , bankruptcy costs are 0.3 , tax rate for corporate income is 0.4 , volatility of annual returns is 0.3 and the tax incidence coefficient $(k)$ is 0.75 . 
Figure 10. Sensitivity of optimal consumption tax to the tax incidence coefficient

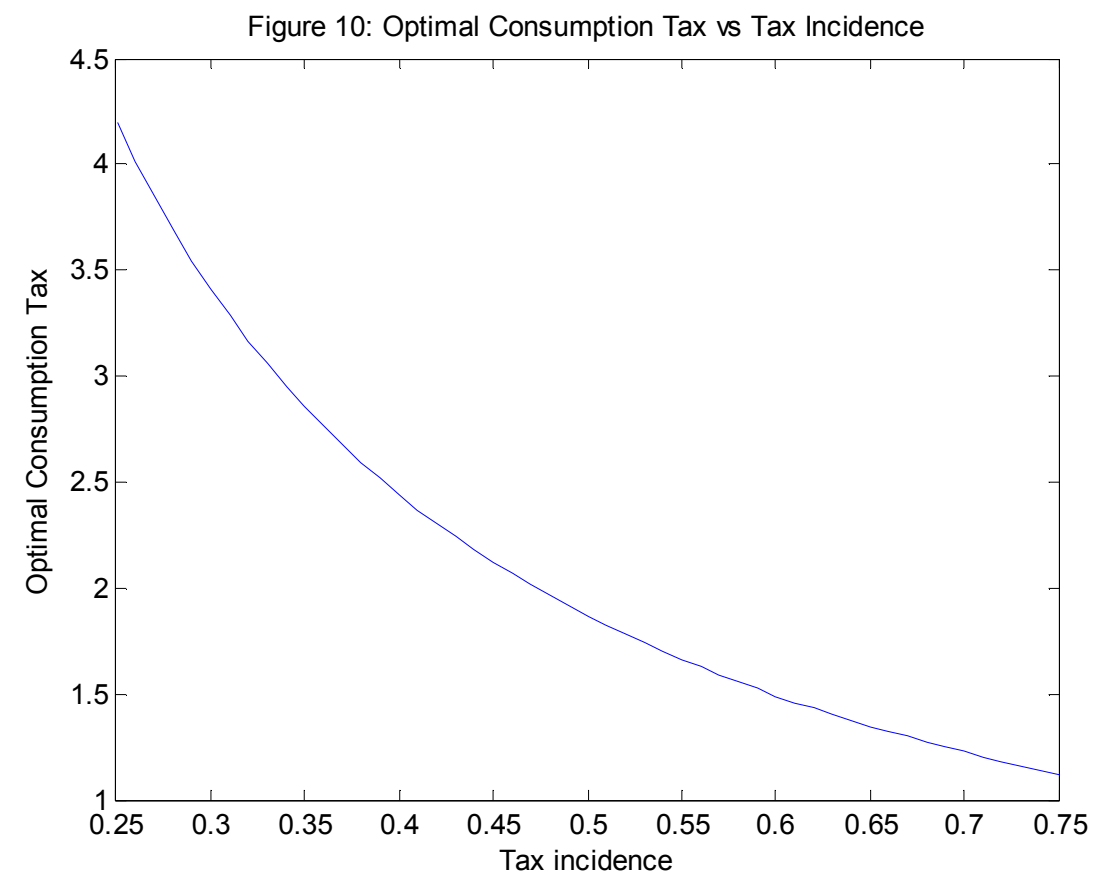

Note: Optimal consumption tax is defined as the level of consumption tax that maximizes the expected government tax revenue. Output price $(Y)_{\text {is }} \$ 1$, coupon payment $(R)_{\text {is } \$ 1 \text {, }}$ operating cost $(C)$ is $\$ 0.25$, investment cost (I) is $\$ 10$, risk free rate of interest $(r)$ is 0.04 , drift rate $(u)$ is 0.01 , bankruptcy costs are 0.3 , tax rate for corporate income is 0.4 and the volatility of annual returns is 0.3 .

In Fig. 9 we see the effect of an increase in the consumption tax on the expected government revenue. We see that an increase in the consumption tax can generate an increase in government revenue, but, beyond a certain level $-T=1.12$ in Fig. 9- the increased tax burdens discourage investment, reduce the tax base and decrease government revenue. Result 3 synopsizes the findings on the consumption tax and expected government revenue from taxation:

Result 3: The expected tax revenue is initially increasing in the consumption tax, reaches a peak, and then is decreasing in the consumption tax, for higher levels of the consumption tax.

This effect of consumption taxation on expected government tax revenue and its optimal level depends on the level of tax incidence on the producer. Ramsey (1927) has shown that the level of optimal consumption taxation on a given product is inversely related to the product's own-price elasticity of demand. The greater the 
own-price elasticity of demand, the greater will be the tax incidence on the producer, ceteris paribus. Our model on capital structure provides a way to rediscover the Ramsey rule, in the framework of irreversible investment under uncertainty; numerically computing the level of the consumption tax that maximizes the expected government tax revenue, we find that it is decreasing in the degree of tax incidence on the producer and therefore inversely associated to the product's ownprice elasticity of demand. Fig. 10 presents the numerical evidence that lead to our fourth result:

Result 4: The level of consumption tax which maximizes the expected government tax revenue is decreasing in the tax incidence on the producer.

\section{Final remarks}

Corporate finance has shown us that capital structure may depend on the taxes that are imposed on investors on a personal and a corporate level. Consumers are also taxed, however, and these taxes determine their willingness to purchase products and a shift in demand ends up altering the price of products in the market. This mechanism of tax incidence has an effect on corporate profits and thus on the structure of the capital budgeting problems. As the tax incidence on the producer can reduce corporate income, we have discovered that investment opportunities decrease in value and investment implementation is postponed. In a similar vein, consumption taxation can have a negative effect on the level of agency costs of debt, yield spreads and the optimal leverage ratio. The real option effects of consumption taxation and tax incidence also determine the magnitude of expected government tax revenue and thus are significant for the design of tax policies.

Our findings can bear significant implications for future research: empirical work on the determinants of capital structure should include consumption tax and own-price elasticities of supply and demand, as these determine tax incidence. Furthermore, the model that is presented in this paper can be extended to incomplete markets, where information asymmetries and transaction costs intensify the emphasis on agency conflicts and the pecking order theory of capital structure could be more efficient in explaining corporate financial decision making. The extension to incomplete markets is also necessary for exploring interpersonal comparisons and aggregations of utilities, which are indispensible when alternative tax systems are evaluated on their effects on equality, redistribution of wealth, social rationality and welfare. 


\section{References}

1. Atkinson, A.B. and J.E. Stiglitz (1976) The design of tax structure: direct versus indirect taxation. Journal of Public Economics 6, 55-75.

2. Childs, P.D., D.C. Mauer and S.H. Ott (2005) Interactions of corporate financing and investment decisions: the effect of agency conflicts. Journal of Finance 76, 667-690.

3. Gamba, A., G. Sick, C.A. Leon (2008) Investment under uncertainty, debt and taxes. Economic Notes 37, 31-58.

4. Gordon R, L. Kalambokidis and J. Rohaly and J. Slemrod (2004) Toward a consumption tax, and beyond. American Economic Review 94, 161-165.

5. Graham, J.R. (1999) Do personal taxes affect corporate financing decisions. Journal of Public Economics 73, 147-185.

6. Leland, H.E. (1994) Corporate debt value, bond covenants and optimal capital structure. Journal of Financial Economics 49, 1213-1252.

7. Mauer, D.C. and S.H. Ott (2000) Agency costs, underinvestment and optimal capital structure: The effect of growth options to expand. In: M.J. Brennan and L. Trigeorgis L (Eds), Project flexibility, agency and competition, New York, Oxford University Press, pp 151-180.

8. Mauer, D.C. and S. Sarkar (2005) Real options, agency conflicts and optimal capital structure. Journal of Banking and Finance 29, 1405-1428.

9. Mauer, D.C. and A.J. Triantis (1994) Interactions of corporate financing and investment decisions: a dynamic framework. Journal of Finance 49, 1253-1277.

10. Miller, M.H. (1977) Debt and taxes. Journal of Finance 32, 261-275.

11. Miller, M.H. and F. Modigliani F (1961) Dividend policy, growth and the value of the firm. Journal of Business 34, 411-433.

12. Modigliani, F. and M.H. Miller (1963) Corporate income taxes and the cost of capital: A correction. American Economic Review 53, 433-443.

13. Morellec, E. and N. Schürhoff (2010) Dynamic investment and financing under personal taxation. Review of Financial Studies 23, 101-146.

14. Ramsey, F.P. (1927) A contribution to the theory of taxation. Economic Journal 37, 4761.

15. Sarkar, S. (2008) Can tax convexity be ignored in corporate financing decisions. Journal of Banking and Finance 32, 1310-1321.

16. Stretcher, R. and S. Johnson (2011) Capital structure: Professional management guidance. Managerial Finance 37, 788-804.

17. Wu L and H. Yue (2009) Corporate tax, capital structure, and the accessibility of bank loans: Evidence from China. Journal of Banking and Finance 33, 30-38. 